\title{
Early Macro Divergence from Micro: Keynes vs Hayek, Fisher and Friedman
}

\author{
Max Gillman*
}

University of Missouri, St. Louis, 1 University Boulevard, Department of Economics, St. Louis, MO 60311, USA

\begin{abstract}
The paper presents facts and theory of the Great Depression that led to the clash of the Neoclassical ideas of Fisher and Hayek with the new interventionalist concept of Keynes. The Keynesian Cross arose to explain how government could create new investment and allow the economy to rise from Depression. Fisher and Hayek instead emphasized banking and monetary policy with "reflation" of price stabilization, upon which Friedman built. The Great Recession policy today echoes more firmly the ideas of Fisher and Hayek in avoiding another depression.
\end{abstract}

Keywords: Debt-deflation, money supply, government spending, currency to demand deposit ratio

\section{FACTS OF THE GREAT DEPRESSION}

The Great Depression of the 1930s occurred internationally and in the US. This deep, prolonged recessionary period was called a depression because of its severity. It arguably transformed what was at the time called Economics into two main strands that became known as Microeconomics and Macroeconomics.

The arising of a separate economics dealing with the aggregate economy apparently emerged from the extreme focus that the economic crisis imposed upon economists of the day. Statistics of the aggregate economy show that the market economy was in danger of collapse. Along with fear of the collapse of the market economy, there was fear of the collapse of democracy itself. During this period extreme political forms that were different from democracy arose more strongly, in particular, fascism and communism.

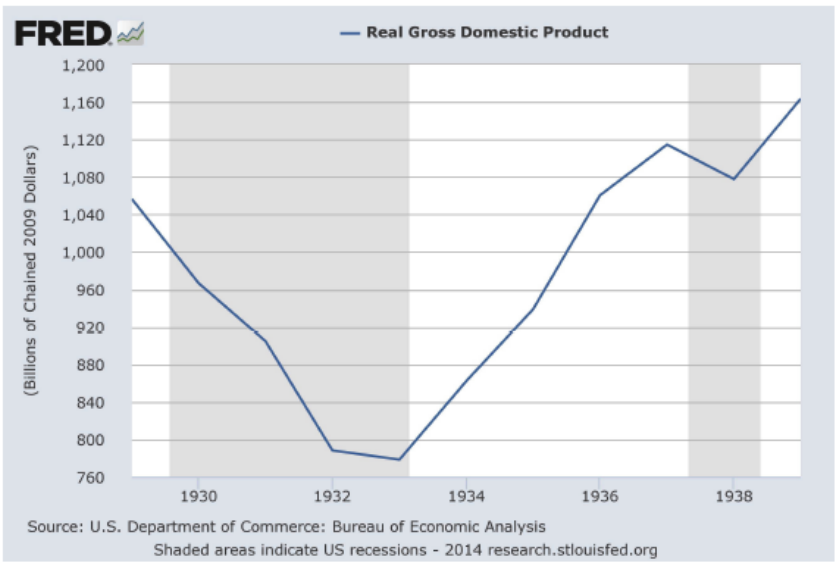

Figure 1: US Real GDP in the 1930s.

*Address correspondence to this author at the University of Missouri, St. Louis, 1 University Boulevard, Department of Economics, St. Louis, MO 60311, USA; E-mail: gillmanm@umsl.edu
For a view in terms of real GDP, Figure 1 shows the US Real Gross Domestic Product (GDP), in constant 2009 dollars, on an annual basis from 1929 to 1939. The trough in annual real GDP is in 1933, and the trough in quarterly nominal GNP (the only related quarterly data in the Fred data base) occurs in the first three months of 1933. The National Bureau of Economic Research \{NBER) "Business Cycle Reference Dates" dates March 1933 as the trough of the Great Depression (http://www.nber.org/ cycles.html). In this figure and the following ones, the shaded area from August 1929 to March 1933 marks the NBER definition of the time period of the Great Depression.

In the capital markets, the Dow Jones Industrial Average Stock Index (DJIA) rose above 360 in August 1929. After the large stock market crash in October 1929, it later hit its Depression Low of 41.22 on July 8 , 1932, about one-ninth the level of its peak. After rising and then falling again, the DJIA started rising ever upwards after March 1933 and never again reached the Depression era low. The DJIA now stands at 17769 (July 29, 2015). In the labor market, equally striking was the change in the unemployment rate. Figure 2 shows the US unemployment rate from April 1, 1929 to June 1, 1942. Although real GDP recovered to above 1929 levels in 1936, unemployment still remained high at $15 \%$ in January 1936 , after having peaked at $25 \%$ in 1933. It fell once again to the near-0 level of August 1929 only in June 1942, as wartime spending began to increase dramatically.

Meanwhile the US CPI inflation rate, from January 1923 to January 1939 is shown in Figure 3, on an annual basis, using monthly data. The point of March 1933 shows an inflation rate of $-10 \%$, a strong deflation. From March 1933 to November 1933, the 
inflation rate rises by 10 percentage points to a rate of $0.0 \%$. This is an increase of the inflation rate level by $10 \%$ in just eight months. This is even more dramatic than the fall in the inflation rate from April 1930, when it was $0.6 \%$, to June 1931 when it was $-10.1 \%$. This drop took more than a year and was of similar magnitude to the rise in the inflation rate after March 1933. But the increase from March to November, 1933, took place in three-fourths of the time period of the April 1930 to June 1931 fall in the inflation rate.

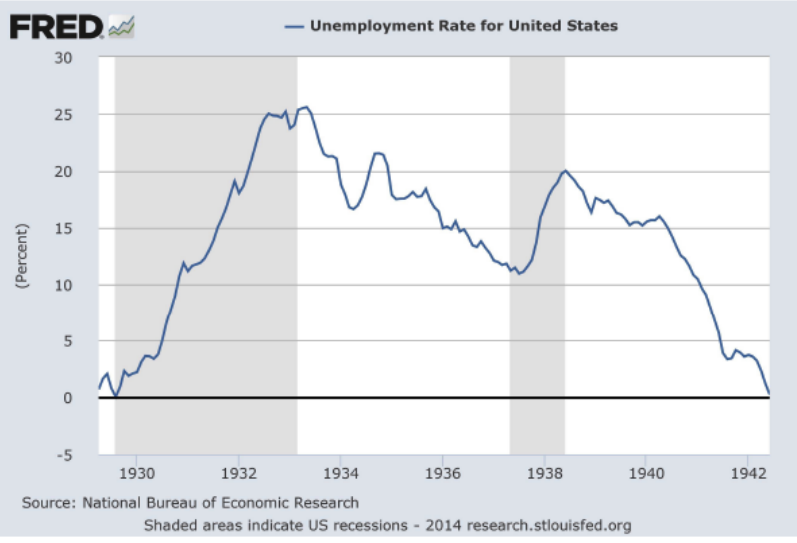

Figure 2: US Unemployment Rate, 1929-1942.

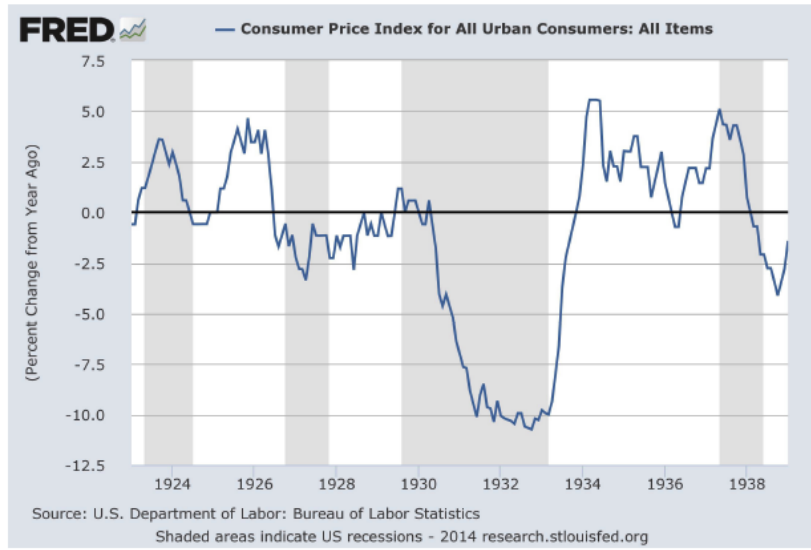

Figure 3: Percentage Change in US Consumer Price Index, 1923-1939.

Another revealing fact was that private bank deposits as a share of the US money supply dramatically rose starting in March 1933. A chart available on Fred shows the ratio of US currency (dollars) relative to the sum of currency and bank deposits. If it rises, then deposits fall relative to currency holding: people take money out of the banks. If it falls, then currency is getting deposited back into the banks, who can then lend it out.

Figure 4 shows that the currency to deposit ratio rose dramatically starting at the end of 1930 , meaning people began withdrawing deposits from banks, until it peaked at $17.27 \%$ in March 1933 . The ratio then fell quickly as people began putting their money back in banks as deposits, and it stabilized around at around $12 \%$ after August 1935. This jump down in March also coincides with the turning point of the Great Depression, this being the date during which it is thought that the Great Depression ended.

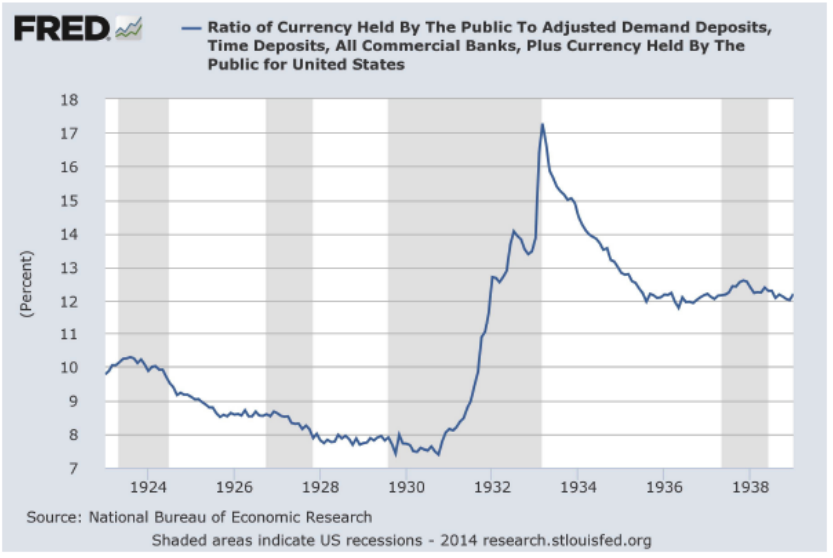

Figure 4: US Currency to Demand Deposit Ratio, 1923-1939.

\section{A. Government Spending including Defense}

There was very negligible federal government expenditure during the Great Depression other than Defense. Including state and local government expenditure the share of GDP of all government spending was $9 \%$ in 1929. Figure 5 shows the total government expenditure as a share of GDP. This share rose significantly during the Great Depression and then drastically starting around 1940 . This 1940 jump can be seen to be a result of the WWII military expense.

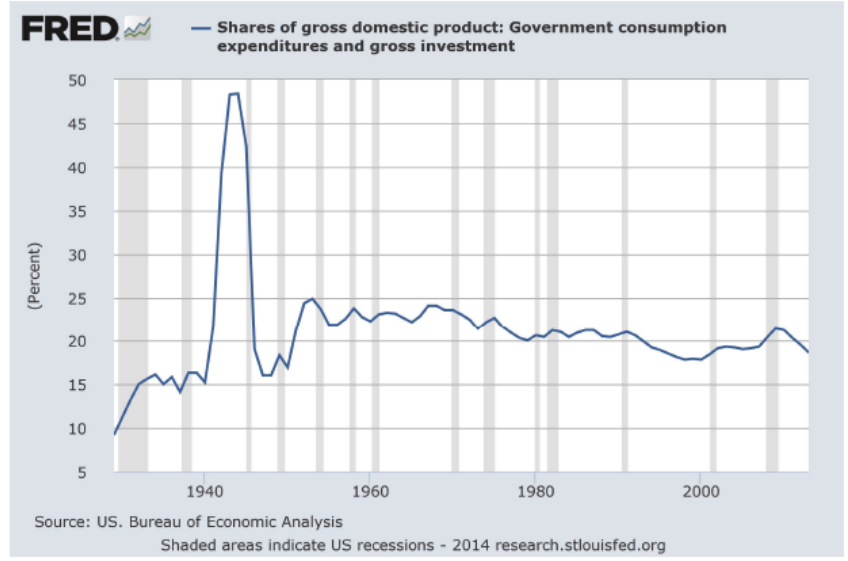

Figure 5: US Total Government Expenditure as a Share of GDP.

Federal Government defense spending as a share of GDP rose from around $2 \%$ in 1940 to over $40 \%$ by 
1944. Figure 6 shows US defense as a share of GDP historically starting in 1900 . The WWII share was twice as high at its peak relative to the WWI share. The Korean War showed a large share near $15 \%$, and since then the defense share has fallen steadily.

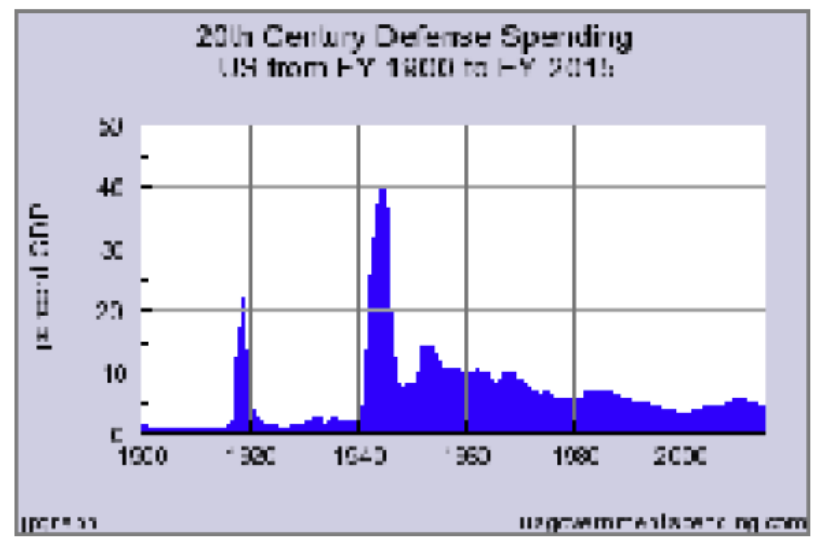

Figure 6: US Defense Spending as Share of GDP, 19002013.

For example, Figure 7 shows that from 1999 to 2014, US defense as a share of GDP fluctuated between $4 \%$ and $5.6 \%$. By comparison the defense share of GDP in the lead-up to WWII and during it was extreme in historical perspective. This suggests that government can influence overall employment, albeit for a wartime economy. However since 2000 Defense accounts for a relatively small share of the total government share of GDP that stands around $20 \%$.

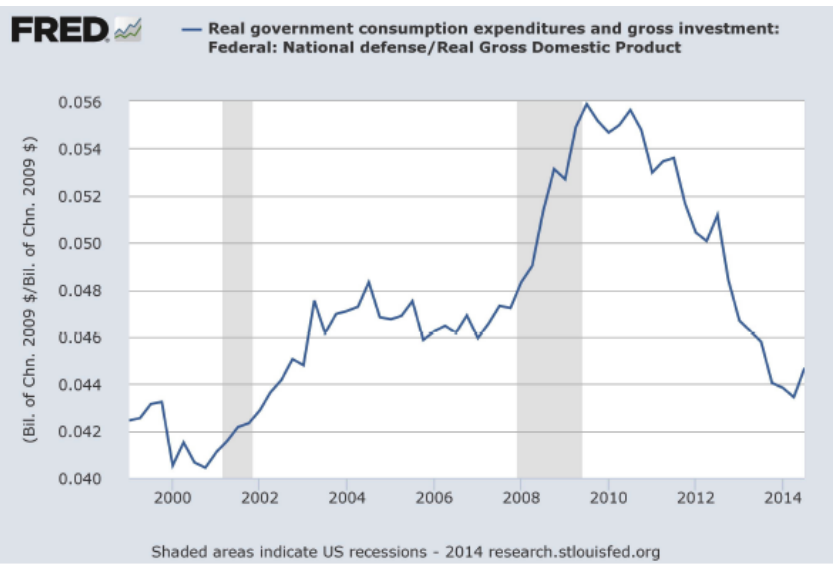

Figure 7: US Real Defense as Share of GDP, 1999-2014.

\section{B. The Great Recession of 2008-2010}

With similarities and contrasts to the Great Depression, a worldwide deep recession took place recently, with it officially (by NBER standards) starting in the US in 2008 and ending in 2010. Figure 8 shows the US growth rate of real GDP with a sharp downturn starting in 2008 and a negative $8.2 \%$ growth rate in the depth of the recession in the fourth quarter of 2008 , using quarterly data. In comparison the 2001 dated recession had a peak decline of $-1.3 \%$ in the third quarter of 2001 . And it compares to a $26 \%$ drop in real GDP during the Great Depression.

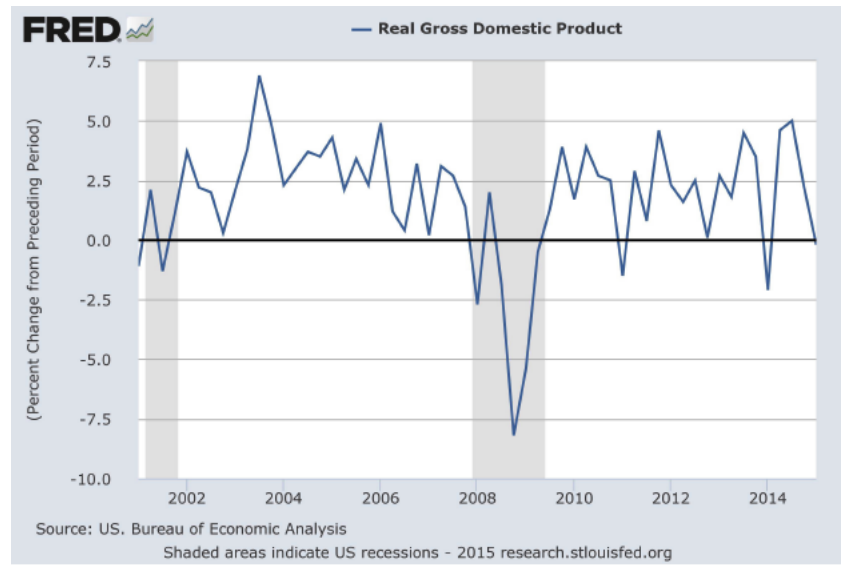

Figure 8: Recent Growth Rate of Real GDP.

In annual terms the Great Recession appears as a relatively small recession historically. Figure 9 shows the US growth rate of real GDP since 1929 on an annual basis with annual data. There is only a $-2.7 \%$ growth rate of real GDP in 2008 on an annual basis. While relatively large in the post-WWII era, it was a small decline compared to the Great Depression (and a brief spike downwards of $-11 \%$ in 1946 after WWII ended).

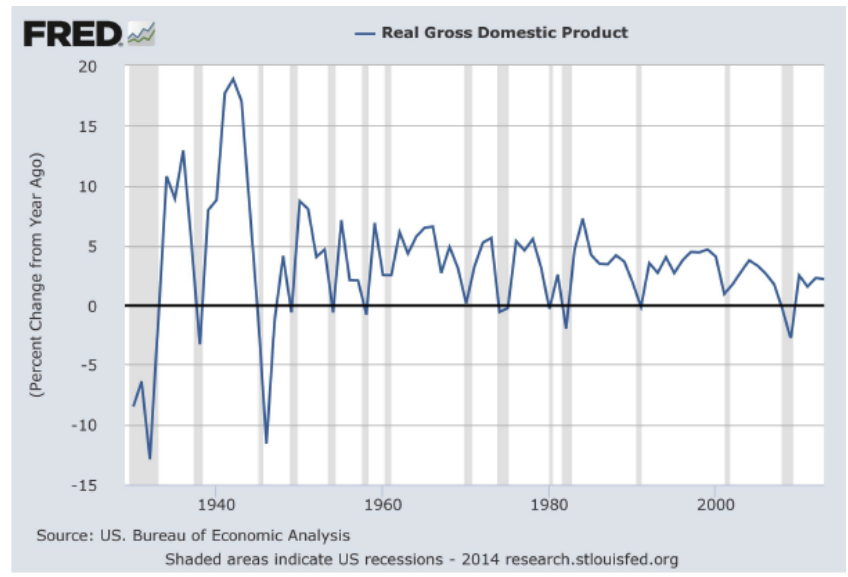

Figure 9: Historical Growth Rate of US Real GDP, 19292013.

The unemployment rate in the Great Recession was prolonged and high, although below that of the Great Depression. Figure $\mathbf{1 0}$ shows the post-WWII US Civilian Unemployment rate. Using monthly data at an annual rate, it peaked at $10 \%$ in October 2009 , less than in 1982 (with a November peak of 10.8\%) but far less than the Great Depression 25\% rate. 


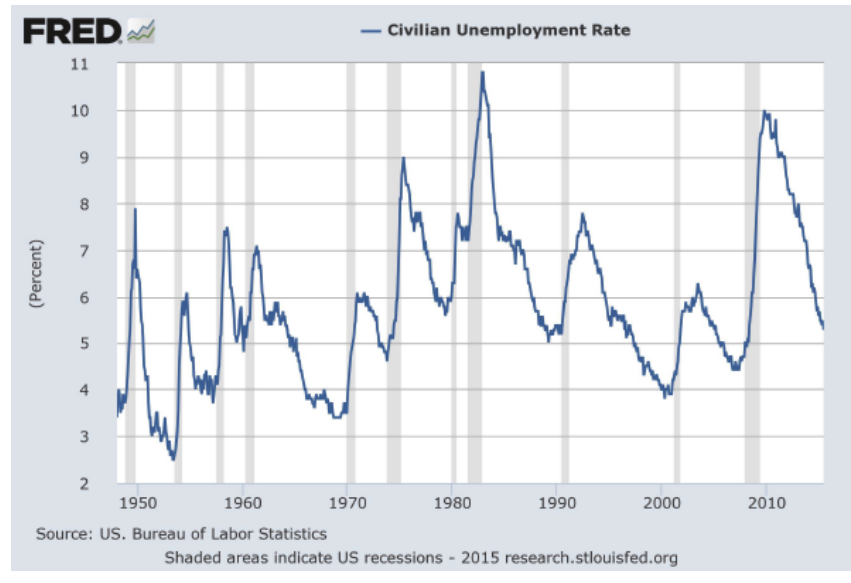

Figure 10: US Civilian Unemployment Rate, Historical.

The stock market crashed in the Great Recession but has recovered and inflation has been low. This stands in contrast to the prolonged stock market crash and the prolonged negative inflation (a 10\% deflation) of the Great Depression. However one other marked feature of the Great Recession is the precipitous drop in the labor force participation rate.

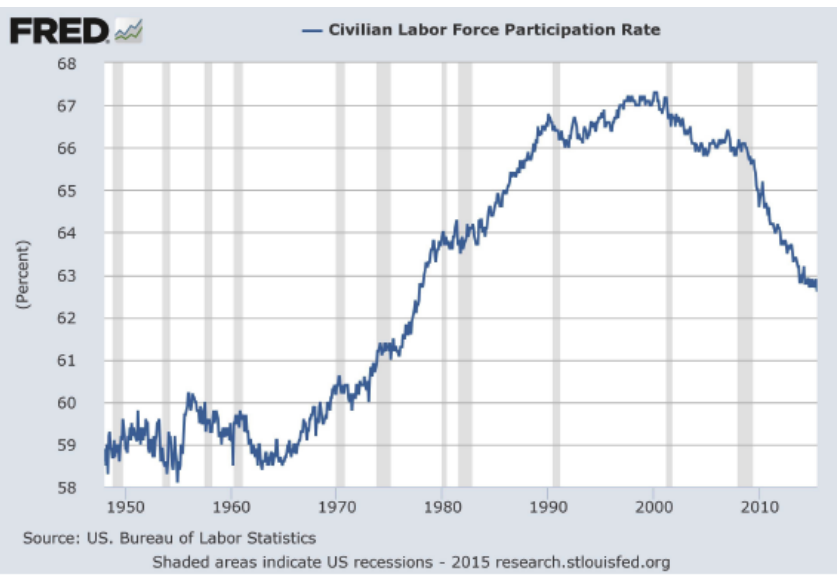

Figure 11: US Postwar Civilian Labor Force Participation Rate.

Figure 11 shows the US postwar Civilian Labor force participation rate. This peaked above $67 \%$ in April 2000, declined somewhat following the 2001 recession, and fell by three points steadily starting in 2009. With a continual decline, it stood at $62.6 \%$ in June 2015 , a level not seen since November 1977.

Non-participation means that workers leave the workforce completely, with them choosing not to participate in the job market. While comparable data is not available for the Great Depression, the data shows a strong postwar upwards trend in the participation rate, with a now reverse trend downwards now just as apparent. This downward participation rate trend is a subject of controversy.
It is interesting to find that the US Census Bureau reports Home Ownership Rates for the US (Table 14) from 1965 to 2015 . The rise and fall in the labor force participation rate and the home ownership move together broadly, both rising into the high 60's percentage in 2000, and falling back to the low 60's percentage in 2015. Houses are typically the biggest wealth asset of households.

\section{THEORY OF THE GREAT DEPRESSION}

\section{A. Neoclassical Approaches}

Neoclassical economists were defined at the time of the Great Depression by using the supply and demand analysis of microeconomics, as developed in the 1870 s (Jevons, Walras, Menger), in trying to describe the entire economy. American economist Irving Fisher developed the analysis of savings and consumption over time. Added to his body of work on interest rates, money supply policy, and on the value of capital, he was the major American voice during the 1920s preceding the Great Depression.

\section{US Home Ownership Rate, 1965-2015}

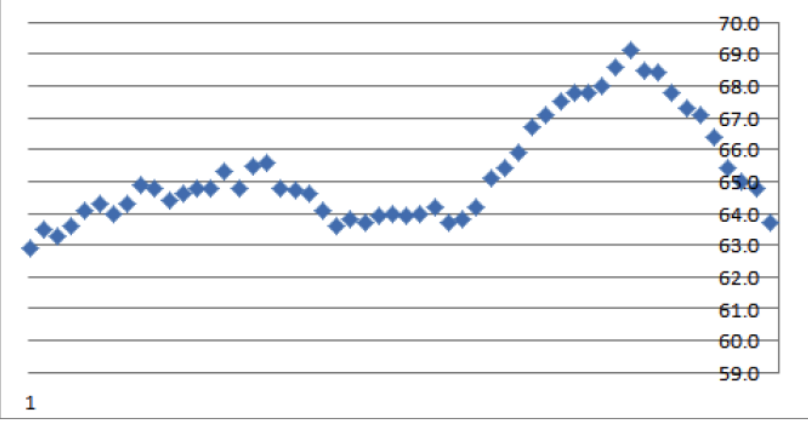

Figure 12: US Census Bureau Home Ownership Rates for the US, on an Annual Basis; Reported Quarterly.

\section{B. Irving Fisher}

Fisher analyzed the Great Depression in terms of supply and demand in his so-called "debt-deflation" theory, as described in his 1932 book Booms and Depressions and his 1933 summary article "The DebtDeflation Theory of the Great Depression". He considers business cycles to be a response to shocks that create dynamic movement around the "ideal equilibrium". There are no set cycles as there are many forces that combine to make each cycle unique. He allows that the entire economy may be in a time of "over" or "under" production of output. And some of these swings in the business cycle can be extreme such that an abnormal crisis occurs. 
Looking at the US' 1873 depression and the Great Depression of the 1930s, Fisher finds that overindebtedness precedes the depression and general price deflation occurs during the depression. As a result of over-indebtedness, default and liquidation of debts then occurs with a host of crescending factors: selling at distressed prices, fewer bank loans and more currency holding combined with less bank deposits, falling general price level, fall in aggregate profits and company net worth, reductions in output, employment and trade, greater loss of confidence and prolonged keeping of money outside of banks that causes the velocity of money in circulation to decrease. Fisher argues that these factors combine to cause abnormally severe recessions that we call depressions.

Fisher finds that the real interest rate rises as a result of the price level deflation and lower money velocity. Here the reduced rate of growth of the money supply is emphasized by Fisher as causing the deflation. This deflation makes existing debt repayment harder, since the real debt burden is higher. This results because making the same dollar amount repayment each month, when the general price level is falling, means the debtor is making higher real repayments. Another way to phrase it is that the real interest rate is higher than when the debt was taken on, as a result of the deflation.

Fisher argues that the way out of a severe debtdeflation type of depression is to "reflate" the price level. He stresses that the primary way to reverse the sequence of events is to increase the money supply so the deflation does not cycle ever downwards. And he argues that this is exactly what President Roosevelt accomplished with a series of legislative and executive actions starting in March 1933. Fisher argues this was the turning point but it would not have happened without the "reflation" policy.

Fisher argues that the banking collapse was the key to the Great Depression. Its ending resulted from the resuscitation of the bank system by various banking Acts starting in March 1933 (see Figure 4 in this regard). Fisher says that just printing fresh central bank (Federal Reserve Bank) money would be an "artificial" reflation that would not work by itself. And Fisher further argues that the Federal Reserve Banks could have averted the Great Depression in the first place with prudential regulation in the beginning after the stock market crash.

Fisher says that too much lending originally leads to over-indebtedness. He stresses that reflation can stop any fall in asset values from becoming extreme by making debt repayment not unusually difficult because of deflation. He equates resorting to pure laissez-faire policy as allowing unlimited bankruptcies. Instead Fisher recommends "medication" in the form of reflation primarily coming from banks making more loans again, rather than only from the government printing money. But explicit in Fisher's remedy is that the government must prudentially regulate or reorganize the bank sector.

Fisher was ahead of his time. His point of view was taken very seriously in the US Great Recession of 2008 to 2010. Remedial legislation was enacted that reformed and subsidized the bank sector and that avoided deflation. The result was exactly that real interest rates did not rise in the Great Recession. Private banks were rescued through a wide variety of measures including restructure through prudential government regulation. And combined with this the Federal Reserve did print a great deal of new currency. Deflation was almost completely avoided.

\section{Frederich Hayek}

Hayek was known for a broad category of social, political and economic theory and application. His 1929 book, Monetary Theory and The Trade Cycle, complements Fisher's perspective. Hayek argues just before the Great Depression that the real interest rate can be lowered below its free-market level by the government. The government does this by persistently printing more money that drives down the real rate of interest in the short term with higher inflation a threat looming for later. The lower real interest rate causes "over- indebtedness" in Fisher's terms. Hayek argues that the credit upswing and cycle occurs because of both private and government action to inflate the money supply through greater indebtedness of both private firms and the government.

Hayek focuses on the private banking system mainly and how credit is expanded when the bank system as a whole increases lending, through the collective action of each of the private banks. He includes discussion of a "pyramid of credit" that is based on insufficient fundamental future ability to repay the debt. He suggests that a general contraction, or recession, can result when the debt load is too heavy to be repaid.

In short he blames a type of natural overinvestment, and its coincident high level of credit as the reason the cycle can collapse downwards. And astutely 
he notes that the Central Bank needs to replenish bank reserves when necessary. Hayek's necessary replenishment of private bank reserves did not happen sufficiently during the Great Depression until the bank Acts starting in 1933.

Hayek argues that such high levels of credit should have been avoided in the first place by rising real rates of interest for example for loans by private banks from the Central Bank. Hayek calls the business cycle by its alternate name at the time, Trade Cycle, and says that both monetary factors and non-monetary factors can contribute to a credit boom, and downwards cycle. And with a focus on banking, he stresses that somehow the private banking activity needs to be kept reasonably stable.

Hayek's 1931 book, Prices and Production, reiterates his previous theory and reviews a great body of monetary, classical and neoclassical literature. The emphasis stays on the banking system and on how the general price level can cause inflation or deflation that affects the real rate of interest. This is the so-called liquidity or illiquidity effect of unexpected inflation, or deflation, on real interest rates.

\section{Milton Friedman}

Hayek in the 1950s became a colleague of Milton Friedman at the University of Chicago, and co-founded the Mont Pelerin Society with Friedman, although their views on monetary theory and business cycles may have diverged. Friedman focused on monetary theory through the supply and demand for real money. He argues that the US depressions were largely influenced by poor money and banking policy.

Friedman built largely on Fisher's theory of savings and consumption in formulating his permanent income hypothesis of consumption. Using optimization theory, Friedman's consumption theory followed Fisher by saying that the consumer wants to optimally smooth consumption over time. This made current consumption a fraction of permanent income.

Permanent income can be thought of as the expected average income stream over the entire future horizon. The idea here is that current income may be temporarily low or high and does not as directly affect current consumption as does the expected permanent income stream.

Friedman also extended Fisher's monetary theory known as the quantity theory of money, including a focus on the velocity of money. And Friedman also was known as was Fisher for advocating aggregate price level stability. Friedman advocated accomplishing price stability, as did others, through a steady growth rate in the money supply.

Fisher, Hayek and Friedman all lacked proposals for strong government intervention to raise consumption and output during periods such as the Great Depression, except for in the area of money and banking policy. They did not focus on the government increasing investment, but rather on the private bank sector being able to once again resume its role in making loans that became new investment. This body of neoclassical theory therefore emphasized private banking and governmental central banking rather than government intervention in terms of expenditure unrelated to banking.

\section{E. Keynesian Economics}

In contrast to this, the Great Depression brought about new economic theory that became known as Keynesian. This was advocated after the Depression and in modern times. A revival in Keynesian-based discourse came during and after the Great Recession. This Keynesian theory is named after John Maynard Keynes. In broad summation, this theory favors the Macroeconomic policy of greater government spending and private market intervention in order to end recession or depression. It argues that monetary policy is less important and has always lacked a focus on banking policy, until recently.

Before the Great Depression J. M. Keynes was known for his work recommending changing the terms of the 1919 Versailles Treaty that ended WWI and demanded war "reparations" from the losing Central powers, especially Germany, to victorious nations. Keynes $(1919,1922)$ predicted this would bankrupt Central nations and cause further world economic disruption. He recommended canceling the war payments for damage done during the war. In fact, Germany made more than a third of the payments but soon fell into a deep hyperinflation, with inflation rates rising to $41 \%$ per day, and $322 \%$ per month. Keynes' predictions of the economic crisis war reparations would cause were prescient.

In 1923, Keynes then published his Tract on Monetary reform. This was based closely on the monetary theory of Irving Fisher. It advocated stabilizing the price level as did Fisher. This was 
consistent with other Neoclassical economic theory that was dominant at the time.

Keynes broke from this tradition during the Great Depression with the publication of his 1930 Treatise on Money. This book presented a theory of the business cycle. It goes on to argue that stronger direct government intervention than monetary policy could positively reverse a cyclic downturn and end a recession.

Keynes based this theory on a different theory of the aggregate price level than is found in Fisher's quantity theory of money. Instead Keynes argues that the price level of aggregate output could be considered to be based in cost theory, as in the microeconomic theory of the firm, rather than based in monetary theory. This amounted to a novel theory of the determination of the aggregate output price level.

Keynes' (1930) new approach to the aggregate price level marks a major break for Keynes relative to his past work. Keynes' (1930) theory of the aggregate price level is as in the microeconomics of Marshall (1920), with no association to the money stock. In particular, Keynes said that the price of aggregate output was equal to the average cost $(A C)$ of aggregate output plus the per-unit profit from producing the aggregate output.

In Marshallian Neoclassical economic theory, the price of a good in any market equals its average cost plus profit. This price also at the same time equals its marginal cost $(M C)$ of production. This is still the foundation of the microeconomic theory of the firm's price for any one good (with profit equal to zero in perfect competitive equilibrium). Keynes' innovation was applying this Marshallian theory of the price to the aggregate economy.

Keynes (1930) left aside the marginal cost part of Marshall's price theory, by which price equals marginal cost. Instead Keynes took the other equivalent part of Marshall's price theory whereby the price of aggregate output is equal to the average cost plus profit per unit of aggregate output. Price equaling average cost plus profit became the basis for Keynes aggregate theory.

Keynes (1930) proceeds then to turn this price theory into a theory of business cycles with profit, savings and investment playing a key role. Within this business cycle theory, Keynes argued that profit was determined by the difference between investment and savings. With more profit, Keynes argued the economy could turn back towards expansion.

In the face of a dearth of private sector investment, which Hayek and Fisher focused on as well, Keynes argued that increased government expenditure could act as new economic investment in place of the banking sector's role in facilitation such new investment. The idea was that this direct federal government investment would then raise national output and income. Using a focus on savings and investment, this proactive role of government became the most enduring part of the theory.

Keynes' (1936) book, The General Theory of Employment, Interest, and Money, further detailed elements of Keynes theory of how increased government expenditure could increase output. In Macroeconomic textbooks, Keynes' $(1930,1936)$ price, business cycle, and policy theories evolved into what became known as the Keynesian Cross analysis, starting in the 1950s and persisting until now. This analysis included a role for consumption such that there could be a multiplier effect from government spending.

\section{F. Aggregate Output Theory with Government Spending}

It is now rather a curiosity that Keynes' (1930) price theory argues that aggregate profit is defined as aggregate investment minus savings. This definition of profit in Macroeconomics is rejected now in a consensual fashion. Such particulars of Keynes' (1930) theory are not used today.

However Keynes $(1930,1936)$ stated that firms would expand when making profit and contract when making losses, which makes sense to a wide array of economists. And further his main argument was that when private investment was insufficient, the government should step in and make investment for the private economy by using unused, excess savings. This intervention would take the form of increased government spending designed to stimulate the economy.

The foundation of excess savings also became a largely unused part of the theory. Instead of a focus on savings alone, the focus shifted also to consumption. The idea of an aggregate consumption function endures to this day, and Keynes (1936) made use of this concept to argue for increased government spending to cause increased consumption. 
Earlier, Fisher had analyzed consumption and savings theory based on current and future income using neoclassical general equilibrium theory. Keynes instead postulates consumption simply as a function of current income and does not focus use the optimization theory that is the foundation of neoclassical economics. This led Keynes to a theory of how government spending can cause greater consumption and aggregate output.

\section{G. Keynesian Consumption Theory}

Keynes' (1936) theory of consumption has evolved to a simple form that appears consis tent with his original concept. The simple form of the aggregate consumption function is that it has three features: 1) consumption depends in a linear fashion on output, 2) consumption has a certain positive level even when output is zero, and 3 ) the rise in consumption is always less than proportional to the rise in output.

The assumptions about the consumption function imply a unique form. Using nominal notation and so ignoring inflation differences that distinguish nominal from real, denote aggregate consumption by $C$. Let $a$ and $b$ be some positive parameters, with the key assumption that $b$ is positive but less than one: $0<b<$ 1. Denoting total (nominal) aggregate output by $Y$, the consumption function follows as:

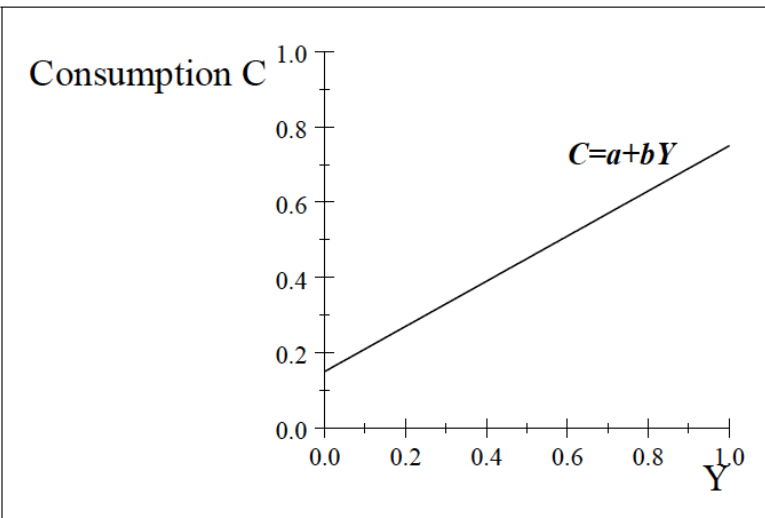

Figure 13: Keynesian Consumption Function, $C=a+b Y$.

$C=a+b Y$

Figure 13 graphs the $C$ function, with $C$ on the vertical axis and $Y$ on the horizontal axis. It assumes that $a=0.15$ and $b=0.6$. The graph is a line starting from a vertical axis intercept of 0.15 , where output is zero.

When output rises, consumption also rises. But consumption rises by less in proportion to the rise in output. This is because the parameter $b<1$. If $b=1$ and a were close to zero, then consumption would rise at the same rate as does output.

Note that since the parameter $b$ shows how much consumption $C$ will increase at the margin when income $Y$ goes up. So the change in $C$ divided by the change in $Y$ is equal to $b$ for a small amount of a change in $Y$. This marginal effect of $Y$ on $C$ causes the parameter $b$ to be called the "marginal propensity to consume".

\section{H. National Accounting and Keynesian Cross}

Now consider adding together the aggregate consumption and the aggregate investment. Denote this investment again by $I$. Assume a) zero government expenditure, and b) zero net exports as in a closed (no international trade) economy. Then adding these together gives the entire GDP under the assumptions that $G=N X=0$. In other words the sum of consumption and investment is total output.

We can write the aggregate of consumption and output, with not government expenditure and net exports, symbolically as

$$
C+I=Y .
$$

At the same time we know from out national income and product accounting that total GDP output equals the total income GDI. This gives us a line that can be graphed as

$$
Y=G D I .
$$

The Keynesian Cross can be graphed simply by graphing the two lines, of $C+I=Y$ and

$$
Y=G D I .
$$

One additional assumption, call it $\mathrm{c}$ ), is that investment is independent of output. ${ }^{\dagger}$ This goes against strong empirical correlation between current output and investment. However, it is convenient here for a proposition of how government spending can increase output. So we will assume investment is constant. For example it equals an amount $d>0$ where $d$ is just a parameter like the ones $a$ and $b$ with the only restriction being that $d$ is positive.

With constant investment, and the consumption function $C=a+b Y$, the sum of consumption and investment now involves a constant, $a+d$, which is the vertical axis intercept of the line $C+I=(a+d)+b Y$. 
Therefore graphically adding investment to consumption just shifts up the line, keeping the slope the same.

Figure 14 shows in the blue line the combined $C+I$. It shows a shift upwards, by the amount $d$, of the $C$ line. A difference is that now we can also say that $C+I=Y$, which we cannot say for consumption alone. In the example, we assume that $d=0.1$ while $a=0.15$ and $b$ $=0.6$. So that $C+I=(0.15+0.2)+(0.6) Y$.

We can now add the line that $Y=G D I$. Since aggregate output and income are equal, and since $C+$ $I=Y$, we can add this as an identity showing that output equals income. If we graph it, we include output $Y$ as an additional vertical axis variable, and GDI as an additional horizontal axis variable. By adding this line, we are adding what is called a 45 degree line, since its slope is one, and the angle of the line from the origin is 45 degrees. Figure 14 combines the three lines of $C=$ $a+b Y, C+I=Y$ and $Y=G D I$.

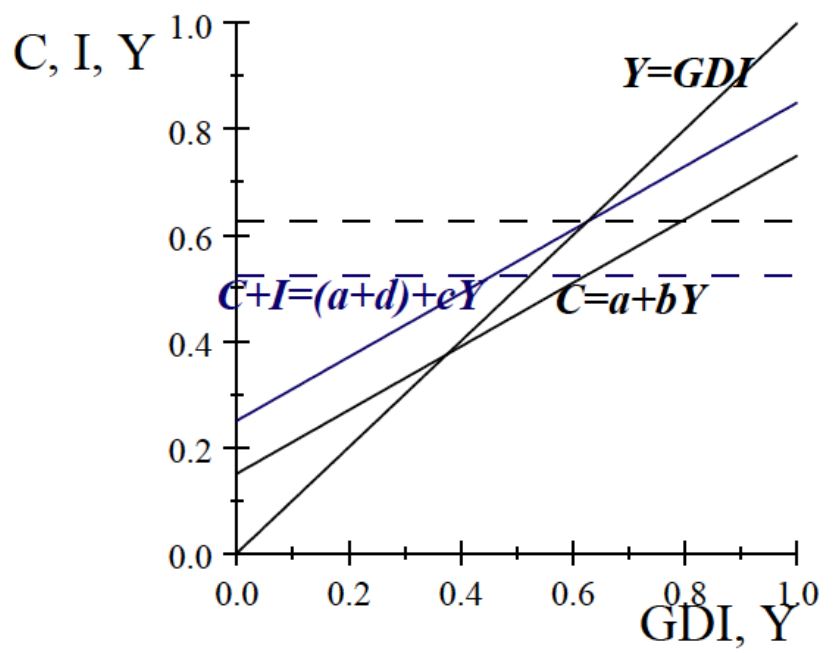

Figure 14: Adding in the $Y=G D P 45 \%$ line, with the $C$ and $C+I$ Lines.

In Figure 14, the intersection of the $C+I=Y$ and the $Y=G D /$ lines gives the equilibrium in the economy. This is in the sense that we can read off the equilibrium amount of consumption, investment and output from the vertical axis. The equilibrium output level is given by $Y=0.625$ as in the green dashed line.

\section{Multiplier and Government Spending}

A key idea of using the so-called Keynesian Cross is to show the effect of government spending on output. It depends closely on the nature of the equation for the consumption function. For example, if we used $C=b Y$, a version of consumption advocated by Milton Friedman which has zero as the vertical axis intercept $(a=0)$, we could not graph this with an equilibrium existing in this diagram, in the sense that $C=b Y$ would not have an intersection with $Y=G D I$. So the consumption function and indeed the whole "Cross" graph is Keynesian in nature.

The consumption function form with $a>0$ and $b<1$ allows for a so-called multiplier effect of government spending. This multiplier arises because when we add any type of new investment, then output and consumption both rise. If the multiplier $1 /(1-b)$ is greater than one, then the increase in the output is greater than the increase in the investment.

Government enters by making the assumption that government spending is like additional new investment in the economy. So if federal government non-defense spending is near zero as it was before the Great Depression, then we can think of $G=0$ now going up to some new amount such as $G=0.10$. This increase in $G$ above zero makes the accounting identity now $C+$ $I+G=Y=G D I$. And since $G$ is just a constant, like investment, it shifts up the $C+I$ line along the 45 degree line to a new equilibrium with a higher output.

The idea behind set of logic whereby government spending is new investment comes from Keynes who suggested there was "excess savings" during the Great Depression that was not being used. So the government should step in and get the savings from the private sector and spend it. With a multiplier above one, which holds for all $b<0$ with the Keynesian consumption function, such government spending increase would raise output by more than the government spent. This was an attractive idea in the time of a Great Depression.

\section{J. Taxes to Finance Government Spending}

Government spending can be included in the Cross model. However this addition brings up the issue of how the spending is financed. In national income accounting we include taxes, but did not in the above Cross analysis. Even if we assume the taxes will only be raised at some time in the future, the correctly expected future taxes would decrease output below that given by the multiplier assumptions. Also disincentive effects on output that usually occur from taxation would additionally lower output.

Suppose when government spending was increased that taxes were increased by the same amount so as to finance the spending. This would be a 
balanced budget increase in spending. It may not be optimal in the middle of a Great Depression (as President Hoover found out when he signed exactly such legislation in the Revenue Act of 1932). In fact, within our analysis the result is clear. Output would not increase at all.

For example let taxes rise by an amount $T$ whereby $T=G$ and $G$ is the increase in spending as in the Great Depression. We call $T=G$ the "government budget constraint" and it is a balanced budget. Now GDP is $C$ $+I-T$ before factoring in the increase in government spending. Once we do add the new spending, we get that $C+I-T+G=Y$. Since $G=T$ the increase in spending, $G$, is cancelled out exactly by the increase in taxes, $T$ so that aggregate output would not change.

The whole idea of the Keynesian Cross model is that payment for the spending is simply not included in the logic. For example if the government issues new debt and borrows to cover its deficit spending, the idea is that the economy would not consider the new debt as a future tax burden that would inhibit current consumption or investment. The Neoclassical Ricardian theory of the government debt, in contrast argues like David Ricardo in the 1800s that government debt must eventually be paid off.

Ricardian debt theory suggests that the future taxation required by additional government borrowing will be considered as a liability by consumers and firms. As a consequence, this liability arguably will decrease consumption and investment even in the present time.

The "multiplier" on government spending would accordingly then be less or even negative.

\section{K. Stabilization Policy Arises}

Paul Samuelson (1951) bases his Cross analysis just as above. And this is the form common in most macroeconomic textbooks to this day, a mark of Samuelson's influence. Samuelson (1951) includes how Investment minus Savings occurs but he does not explicitly call $(I-S)$ profit as does Keynes $(1930,1936)$. Modern textbooks usually leave out any discussion at all about $I$ being different from $S$ since most of our equilibrium analysis has that savings always equals investment (except for the cost of intermediating the savings from consumers to firms through banks, for example, or when there is international capital trade).

Samuelson goes on to describe the Great Depression in his Chapter 13 with the aggregate "cross" analysis. He says that the actual output during the Depression was below the hypothetical level of the "full employment output". This full employment output level is supposedly the level achieved over time if the economy keeps growing at its previous historic full employment rate such as during the 1920 s expansion.

Samuelson argues that federal government spending can enable the economy to close the "gap" between the full employment level of output and the level during the Depression. He uses the Keynesian Cross analysis above to show this. And this gap is now known as the output gap.

Therefore the idea of the Cross, in current macroeconomic textbooks, avoids the original motivation of profit equaling $(I-S)$ and instead just shows how an increase in $G$ lifts the economy. Textbooks currently use notions of national income accounting and sometimes use the Cross to discuss aggregate supply and aggregate demand.

Samuelson also presents taxes as reducing output, but offers that the net effect of spending can still be positive. And we are left then with the theory that recessions, or Great Depressions, can be eliminated by government spending: Any kind of government spending. If true, then we always could always stay at the full employment level and have no business cycles of expansions and recessions. This view of perspicacious government spending became known as stabilization policy.

\section{APPLICATION: CROSS ANALYSIS OF GREAT DEPRESSION}

Keynes idea was that one way to get the economy back up to its previous position is to increase government spending. If the economy has already gone down to a lower $C$ and a lower $I$ and so a lower $Y$, as in the Great Depression, then a Keynesian answer for this would be to bring the economy out of the recession by spending money $G$. This can be illustrated by using years to mark the level of GDP.

Say in 1929 , output is equal to 0.75 so that GDP in 1929 is $Y_{1929}=0.75$. Then the stock market crash occurs, firms cannot repay loans, the bank sector collapses, and investment falls. In addition, as workers get paid less and capital owners earn less, consumption also falls. So say the 1933 output is now $Y_{1933}=0.56$ a reduction of output by $25 \%$ as actually occurred in the Great Depression. 
Illustrate $Y_{1929}=C+I=0.75$ in Figure 15 by the purple line. This falls to $Y_{1933}=C+I=0.56$ as illustrated by the blue line. Here $C$ and $I$ both fall from their 1929 level to the assumed 1933 level of 0.56 (so that the output decrease is $25 \%$ ). Here we assume that in $1929 a=0.18$ and $d=0.10$. And in 1929 these consumption and investment parameters, respectively, each fall by about $25 \%$ to $a=0.135$ and $d=0.089$.

With a multiplier of 2.5 assume that government spending of $G=0.076$ occurs. Then the output increase from the new government spending is found as 0.076 times the multiplier of 2.5 . This equals 0.19 . Adding this to the depression output level of 0.56 gives an output level of 0.75 , the same as before the Depression started, back in 1929.

Now assuming we are in 1933, one Macroeconomic policy answer at the national level for getting out of the Great Depression could be to increase Federal government spending, as Keynes $(1930,1936)$ proposed. Now assume that we increase government spending from the assumed 0 amount in 1929 to an amount in 1933 equal to the drop in output, divided by the multiplier of 2.5. Here we are assuming that although consumption fell, the "multiplier" remains at 2.5 , since the coefficient in the consumption function, $b$, is unchanged at 0.6. Then the amount of government spending in 1933 would be $(0.75-0.56) / .2 .5=0.076$. And as a consequence of $G_{1933}=0.076$, an increase from $G_{1929}=0$, the hypothetical output would rise back up to the level of output that existed in 1929 of $Y=$ $Y_{1929}=0.75$. In other words, the government spending would immediately get us out of the Depression and return us to the 1929 level of real output.

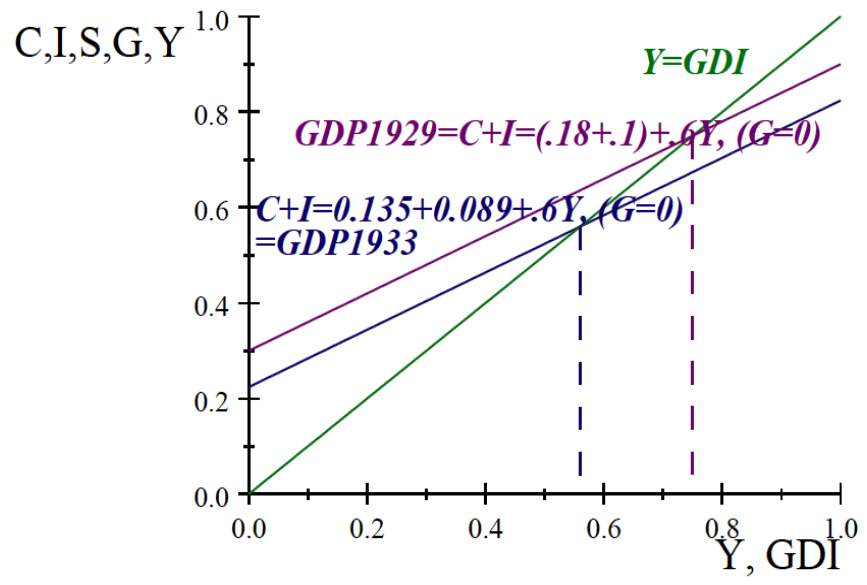

Figure 15: Drop in $\mathrm{C}+\mathrm{I}$ when Consumption and Investment fall in 1933, Compared to 1929.
Figure 16 illustrates this hypothetical increase in output by calling it GDP 1933*. The dotted Black line coincides with the Purple 1929 GDP line. Thus the government spending increase from 0 to 0.05 shifts up the $G D P$ line, and it intersects with $G D I$ at 0.75 . Figure 16 illustrates this by showing a black dashed line that coincides with the original purple line of the 1929 level of output.

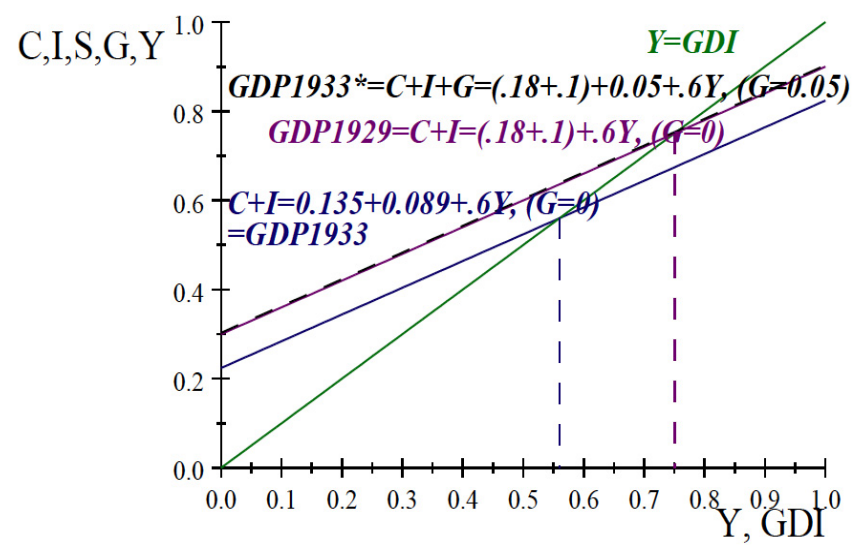

Figure 16: An increase in $G$ from 1933 GDP (in Blue) to get back up to $1933^{*}$ GDP (in Purple, and Black).

\section{SUMMARY}

Neoclassical theory emphasized business cycles and how they occur through the bank system creating credit. Neoclassical economists emphasize that stabilizing inflation is key to avoiding severe recessions that can become depressions if significant deflation is allowed. This stabilizing of the price level comes from a combination of prudential banking regulation and government monetary policy. The Great Depression ushered in theory that challenged the limited role of government in neoclassical theory.

Unemployment during the Great Depression rose to $25 \%$ and only fell down to near zero once the spending by the US on Defense during $W W \|$ accelerated. Government spending was the key to Keynes' proposal of how to raise output during a business cycle recession. Keynes constructed a theory of the price level different from microeconomic Marshallian (1920) theory so as to describe how a business cycle operated.

From this alternate price theory, Keynesian economics developed the Cross analysis which emphasizes how direct government spending is a key to ending a recession. The Keynesian stabilization policy instead involves government spending to act as 
private investment that brings the economy back up to its "full employment level of output".

The increase in output from an increase in government spending would be "multiplied" by a factor based on the consumption function "marginal propensity to consume", which is given above as $b$. The higher would be the government spending multiplier, the higher would be the subsequent increase in aggregate output from an increase in $G$. The multiplier is higher with a lower b because consumption $C$ would be lower and savings would be higher.

The original Keynes idea is that this lower $b$ would make for more "unused savings" during a recession that the government could "utilize" and turn into active spending. Thus the "multiplier" on government spending $G$ is higher the lower is the $b$. This $b$ is the parameter factoring income $Y$ in the Keynesian consumption function.

The current usage of the Cross theory finds recourse in the national income accounting theory whereby output is equal to income. It turns this accounting identity into a theory of how government spending can increase output. It invokes a multiplier theory and ignores taxes used to finance the new government expenditure.

To end depressions, or moderate recessions, Keynesian policy emphasizes government spending while Neoclassical policy emphasizes banking and monetary policy. These divergent views are a broad scope statement of the different perspectives as they occurred historically and are often discussed today. But the contrasting positions are often today much more nuanced. Modern macroeconomics sees government spending and even bank policy often in terms of social insurance for when the markets cannot supply this insurance.

A convergence of these perspectives is possible such as through a social insurance function of government. This has roots in classical and neoclassical economics. Keynes' theory of additional government spending also can be seen from the view of supplying government insurance. This is because additional government spending during a recession often is in the form of explicit social insurance programs that increase spending when the incomes fall. Well-known examples are unemployment insurance benefits, income support payments, and medical and old age benefit support.

Macroeconomic US policy during the US 2008-2010 Great Recession was often called Keynesian for its increase in government spending. However it is often argued that much of this Great Recession spending was used to rescue the US bank system. Such a banking focus was also a focus of the neoclassical economists Fisher $(1932,1933)$ and Hayek (1931).

Today bank insurance has been spread internationally across the globe and much of the worldwide policy reaction to the Great Recession involved bank policy that further insured the soundness of the banking system. This bank policy combined with monetary policy resulted in stable inflation in the Great Recession worldwide as opposed to the strong deflation seen in the Great Depression. This relative price stability accomplished during the Great Recession is what Fisher $(1932,1933)$ and Hayek (1931) stressed was the central policy failure during the Great Depression to which he applied his debtdeflation theory.

\section{REFERENCES}

Fisher, Irving (1932) Booms and Depressions; at https://fraser.stlouisfed.org/docs/publications/books

Fisher, Irving (1933), "The Debt-Deflation Theory of Great Depressions", Econometrica,

October, pp. 337-357; at https://fraser.stlouisfed.org/docs/meltzer/ fisdeb33.pdf.

Friedman, M. (1957), A Theory of the Consumption Function, NBER no. 63, Princeton NJ; Princeton University Press.

Friedman, M. (1960), A Program for Monetary Stability. New York: Fordham University Press.

Friedman, M. and Schwartz, A.J., (1963) A Monetary History of the United States, 1867-1960, Princeton NJ; Princeton University Press.

Friedman, M. and Schwartz, A. J. (1982), Monetary Trends in the United States and the United Kingdom: Their Relation to Income, Prices, and Interest Rates, 1867-1975, NBER. http://dx.doi.org/10.7208/chicago/9780226264257.001.0001

Hayek, F.A., (1929), Monetary Theory and The Trade Cycle.

Hayek, F.A., (1931) Prices and Production

Hansen, A. H., (1953) A Guide to Keynes. New York: McGraw-Hill Book Co.

Keynes, J.M., (1919), The Economic Consequences of the Peace, Macmillan and Co., London.

Keynes, J.M., (1922), A Revision of the Treaty, Macmillan and Co., London. Keynes, J.M., (1923), A Tract on Monetary Reform, Macmillan and Co., London. Keynes, J.M., (1930), A Treatise on Money, Macmillan and Co., Volume I, London.

Keynes, J.M., (1936), The General Theory of Employment, Interest, and Money, Har- cournt Brace Jovanovich, First Harbinger Edition, 1964. 
Marshall, Alfred, 1920, Principles of Economics, 8th Edition, Macmillan and Co., Lim- ited, London.
Samuelson, P. A., (1951), Economics: An Introductory Analysis, Second Edition, McGraw- Hill Publishing Company Ltd, New York.

Received on 19-11-2015

Accepted on 30-11-2015

Published on 16-12-2015

DOI: http://dx.doi.org/10.6000/1929-7092.2015.04.26

(c) 2015 Max Gillman; Licensee Lifescience Global.

This is an open access article licensed under the terms of the Creative Commons Attribution Non-Commercial License (http://creativecommons.org/licenses/by-nc/3.0/) which permits unrestricted, non-commercial use, distribution and reproduction in any medium, provided the work is properly cited. 